\title{
Evaluation of the Convergence of International Markets for Agricultural Enterprises of Ukraine under International Diversification Conditions
}

\author{
By Alona Tanasiichuk ${ }^{1}$, Svetlana Kovalchuk ${ }^{2}$, Olha Hromova ${ }^{3}$, \\ Hryhorenko Inna ${ }^{4}$, Fedortsova Olena ${ }^{5}$
}

\begin{abstract}
It is proposed the classification of indicators of convergence assessment of international markets for determining their marketing attractiveness for the enterprise, which includes absolute and relative indicators of measurement of general statistical data, evaluation of factors of production, information on products and services, dynamic indicators and convergence indicators used by enterprises for the search of new international markets. In the expert assessment of convergence indicators, the markets of foreign countries, the indicators of which are as close as possible to the Ukrainian economy, are distinguished, the result of the assessment allowed to draw conclusions about the marketing opportunities of domestic enterprises in the conditions of the export of goods to the markets of these countries. As the analysis of practical aspects of the functioning of agricultural enterprises and their associations results, a scientific and methodical approach to a comprehensive convergence of agricultural enterprises activities of Ukraine assessment under the conditions of international diversification has been developed. The proposed approach is based on the method of summing up the ranks to rank foreign markets according to the system of dynamic indicators application, which allowed to determine the marketing attractiveness of new international markets for the domestic enterprises activity in these markets and to assess their convergence. As the application of the proposed approach result, foreign markets have been identified which demonstrate favorable conditions for doing business on them, indicating the convergent conditions existence, which is a prerequisite for domestic agricultural enterprises to the markets of these countries release, and also determines the factors and criteria for making managerial decisions regarding realization of domestic agrarian enterprises activity under international diversification conditions. It is proved that the markets of Belgium, Italy, Ireland, Switzerland, and Japan have demonstrated favorable conditions for doing business with them, indicating a significant convergence of markets in these countries. It is determined that the markets of Greece and China are promising for domestic enterprises in the presence of opportunities to overcome a significant margin of discretion.
\end{abstract}

Keywords: convergence, international diversification, international markets marketing attractiveness, convergence evaluation of international markets

\footnotetext{
${ }^{1}$ Doctor of Economics Sciences, Professor of the Department of Marketing and Advertising, Vinnytsia Trade and Economics Institute, KNTEU, Ukraine

2Doctor of Economics Sciences, Professor, Professor of the Department of Marketing, Khmelnytsky National University, Khmelnytsky, Ukraine

${ }^{3}$ Ph.D. in Economics, Associate Professor of the Marketing and Advertising Department, Vinnytsia Trade and Economics Institute, KNTEU, Ukraine

${ }^{4}$ Ph.D. in Technical, Associate Professor of the Department of Commodity, Expertise and Trade Entrepreneurship, Vinnitsa Trade and Economic Institute of KNTEU, Vinnytsia, Ukraine

${ }^{5} \mathrm{PhD}$, Senior Lecturer of German Philology, Department Municipal Higher Education Institution Vinnitsa Humanities and Pedagogical College, Vinnytsia, Ukraine.
} 


\section{Introduction}

In order to diversify the economic ties of Ukraine, the exit of their international markets beyond the economic space it is needed to develop a profitable trade with countries around the world. But Ukraine, unfortunately, nowadays loses its traditional sales markets, so the conquest of new international markets in the world market is one of the most important tasks. The low competitiveness of many goods of our industry leads to a decrease in demand in the traditional market and increases the raw material "shrinkage" of exports, as well as leads to the scientific and technical sphere atrophy and also the processing industries of domestic industry atrophy.

For a significant change of such a condition, a structural adjustment of export potential needs to be carried out in the country, the primary task of which is to stop the destruction of the resource (export) potential. At the same time, a complex of measures aimed at increasing export potential in accordance with the requirements of the scientific and technological revolution has to be gradually implemented, considering international division of labor, potential resources and relative competitive advantages of Ukraine.

In today's economic environment, victory over competitors is becoming a major factor in the efficiency of both domestic and international markets. In accordance with the changes taking place in marketing and international marketing, the focus is shifting into product promotion, and the marketing program is based on the modern concept of integrated marketing communications, which involves the simultaneous and synergistic use of advertising, promotion of sales, personal sales, promotion, and public relations for achieve maximum efficiency of marketing activities of the enterprise.

We believe that the future perspective of developing a new marketing concept under the globalization of economic activity conditions will be convergence, as a prerequisite for the exit of goods into new markets. For some enterprises and groups of goods, this tendency is observed now (Western firms in countries with a civilized economy); however, in order to assess the marketing appeal of new international markets, it is expedient to consider the concept of convergence from the marketing point of view and to determine the methods of assessing the convergence (similarity) - the marketing attractiveness of the new international markets for enterprise activity.

An important stage in the study of the functioning of agrarian enterprises is a comprehensive assessment of new international markets convergence for domestic enterprises under international diversification conditions [13, pp. 99], since the moment when there are no opportunities for trading activity expansion in the old markets, then enterprises have to study the prospects of entering new, more distant markets, or focus on new segments of the old markets.

\section{Literature Review}

The current problem of the present is overcoming uneven economic development of Ukraine, which is confirmed by the convergence process and divergence of its economic space. The tasks of economic growth of the country should be solved in conjunction with the economic aspects of spatial development which is of practical importance. 
Lively discussions about the laws of market development, have been present for more than half a century in the world literature; determine its tendencies as a kind of economic development indicator. Theoretically grounded may be both growth and decrease in cross-sectoral and inter-market differences. In this case, many models have been developed that explain the interaction of adjacent markets. The concept of "convergence" and "synergy" (converge - get closer, go together; convergence- to approach, converge; Synergy- cooperation, commonwealth) is surprisingly similar, which suggests the existence of direct communication and the interdependence between the level of effort uniting and the level of effect, which in this case will exceed the separately operating entities effect.

However, it should be pointed out, and this should become an important criterion and principle of our country's efforts to share the economic potential in national economies different sectors, that the term "convergence" does not merely represent convergence. First of all, convergence is a complex evolutionary process of acquiring relatively remote (non-similar) organisms (biological) of similar anatomical (structural) forms, features, structure and functions due to existence in the same environment or due to identical living conditions adaptation.

This approach in our opinion, at first glance, is inadequate in relation to the approaches of economic analysis. Biological terminology deeply reflects the realities and needs of economic life, institutional environment, prospects of Ukrainian enterprises in the international market. Indeed, one can talk about the real sectoral convergence of national economies, and, moreover, the stable synergistic effect of such convergence only when the same strategic objectives of socio-economic development, the emerging institutional environment of a market economy be achieved, which ensures the uniformity functioning of market mechanisms, separate sectors of the economy and economy in general, real economic freedom of economic entities, political will of power structures, economic needs and interests, realization which will contribute to economic power sustainable growth and well-being of each of the partners.

Considering the conceptual-categorical apparatus of the concept of "convergence" borrowed from the natural sciences, one can see it explains the emergence in the process of evolution in relatively remote groups of organisms of identical features in structure and functions due to their livelihoods under similar environmental conditions.

Domestic experts-economists D. Lukianenko, V. Chuzhikov (2010, 2011) [19, 20] in their scientific works devoted to of global economic development study models and convergence of economic models, argue that more goods and services are being produced for foreign markets rather than for consumption and usage them inside some individual countries [19, 20].

Foreign economists and sociologists used this term to analyze the phenomena of social life, arguing that various economic systems under the influence of modern industrial development acquire common features, converge, merge into a "mixed society", which will embody the benefits they have. Certain aspects of convergence connected with processes of regional economic convergence are covered by leading domestic economists, among them: A. Filippenko, A. Galchinsky, V. Sidenko, Yu. Pakhomov and others (2002) [30].

The term convergence is used in the economy to denote the convergence of different 
economic systems, economic and social policies of different countries, that is, the convergence or alignment of the difference (Korolchuk L., 2012) [17]. Domestic marketing specialists I. Boychuk and O. Musika (2010) [3] determine that in addition to integrating elements of the marketing complex, the market is characterized by the process of convergence. Convergence is called a process that leads to goods and services that were previously considered to belong to different markets in one market. And it is believed that as a result, in fact, all goods compete with each other (this is an understanding of the process of convergence in the broadest sense).

Studying in reality the process of convergence in the market of Internet resources I. Boichuk and A. Muzika (2010) [3] determine the types of convergence from the marketing point of view (Fig. 1).

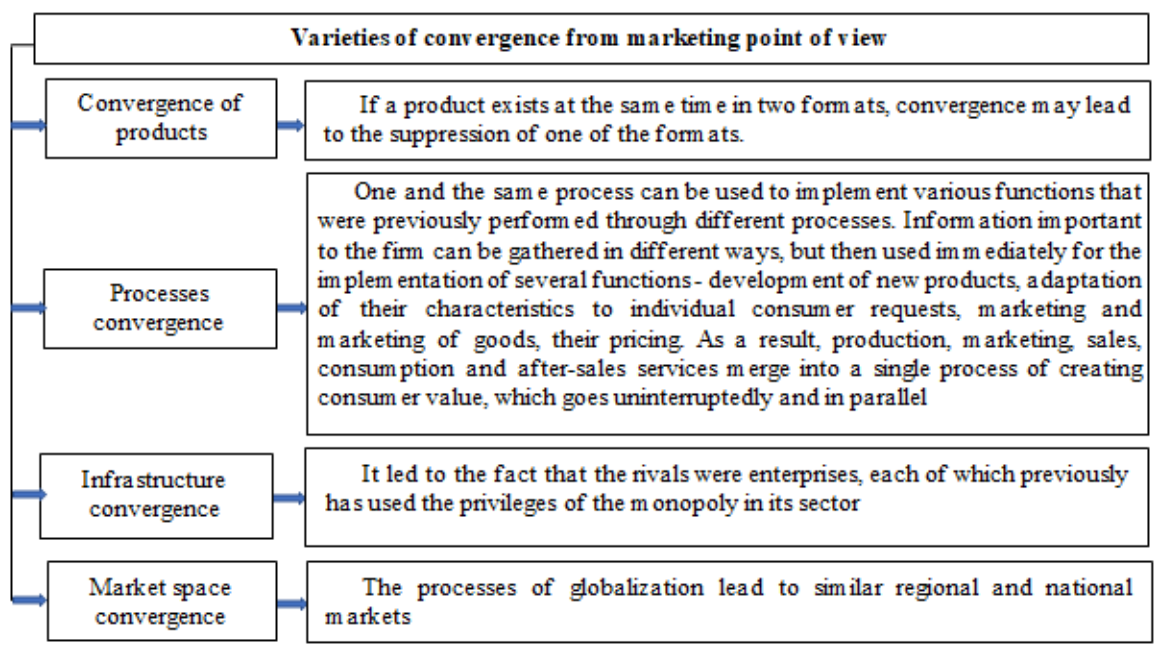

Figure. 1 V arieties of convergence according to the marketing approach

Source: is compiled by the author

Integration processes, the globalization of economic activity, information and network technologies have led to the spread of convergence, that is, the convergence of different countries' economies, attracting more and more countries into international activities. At the same time, there are dozens of the most backward countries belonging to the socalled "world periphery" (first of all, the countries of Africa to the south of the Sahara), which for a number of good reasons are not ready to adapt to the requirements of modern scientific and technological progress, structural changes on the world markets. As a result, the gap between economic development of the leading and underdeveloped countries of the world is increasing, i.e. divergence takes place. According to the UNO, the divergence between the absolute per capita income in one fifth of the richest and one in the fifth poorest countries in the world (2005) [7] deepens.

The creation of a common European market has contributed to strengthening both real and nominal convergence of the EU countries. However, it is impossible to guarantee the stability of nominal and real convergence until they are accompanied by institutional convergence, that is, the harmonization of the activities of economic institutions, as well 
as the establishment of framework conditions that serve as a benchmark for the behavior of individual market players. The so-called Maastricht criteria (1993) [25], which are grouped into two groups: monetary and fiscal (Nedogereeva A., 2006) [25], were based on nominal convergence within the framework of the EU. The first group includes criteria for the level of inflation, exchange rates and interest rates, to the second, the country's debt index. The effectiveness of the convergence process depends on the existing differences in potential, levels and rates of economic development of the countries, and the possibilities of overcoming a significant margin in the main macroeconomic indicators of the countries. The EU ratification agreement of 1994 defines the set of criteria for the entry into the union of new members (the size of the budget deficit of the country should not exceed 3\% of GDP, the size of the public debt must not exceed $60 \%$ of GDP, the rate of inflation is not should exceed the indicator of the three best member countries by more than $1.5 \%$; the long-term nominal interest rate should not exceed the indicator of the three best member countries by more than $2 \%$; the deviation of the exchange rate should not exceed the indicator of three on Best of member countries by more than $2.25 \%$ ) (T. Hryhorets, 2005) [7].

The financial convergence criteria, the achievement or failure of which is determined by the results of the audit by the European Commission and the European Central Bank, is presented in Fig. 2.

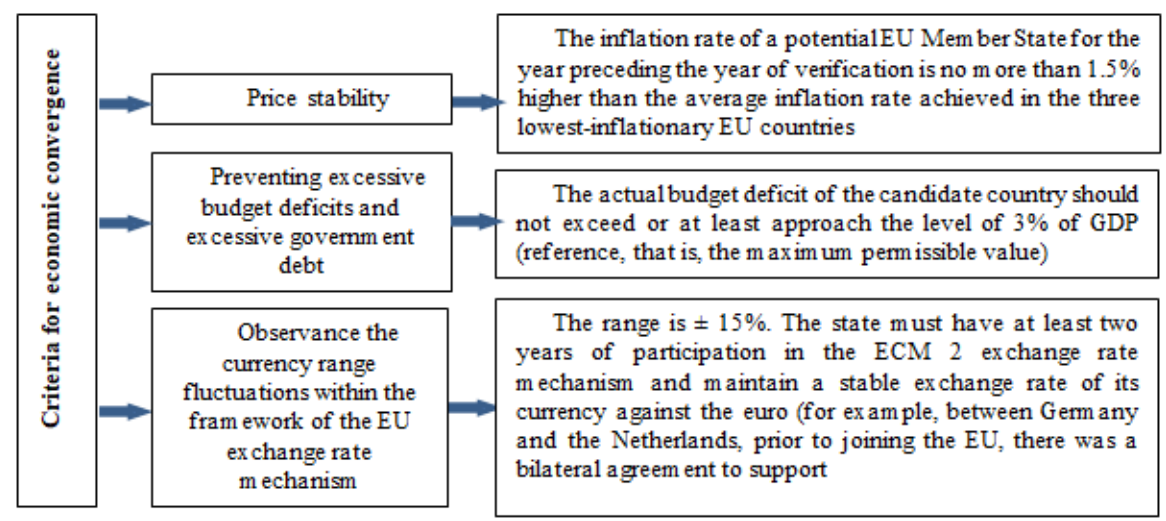

Figure.2 Criteria for economic convergence

Source: is compiled by the author

The main recommendations of the European Commission regarding convergence programs include: reducing the budget deficit through more efficient use of public funds; limitation of medium-term budget expenditures; prevention of inflation growth, (Kovin'ko O. M., 2016) [15].

In modern economic science there are two completely opposite views on the results of economic development in the unregulated market. Neoclassicists (R. Barro, X. Sala-iMartin, (1992) [31], D. Quas, J. Borte, J. Stein (1999) [32] see the end result in convergence (convergence) in income levels and rates of regional development, and supporters of the theory cumulative causality and new economic geography (J. Friedman, P. Coloman, M. Fujita, P. Martin, J. Ottaviano) predict divergence (disagreement) of 
regions according to indicators (Kovin'ko O.M, 2016) [13].

Summarizing domestic and foreign scientists' results of researches, such us R. Barro, Ks. Sala-i-Martin, Kaplan R., H. Mencky, P. Romer, Norton D. and D. Wile, we note that all of them agree that for the estimation of integration processes it will be effective to use quantitative and qualitative statistical information character, which is done during collecting and analyzing and which is grouped into economic integration general system of indicators which allows to assess degree convergence of the investigated structure (1991, 1996, 1999, 2001) [32-34] (Fig. 3).

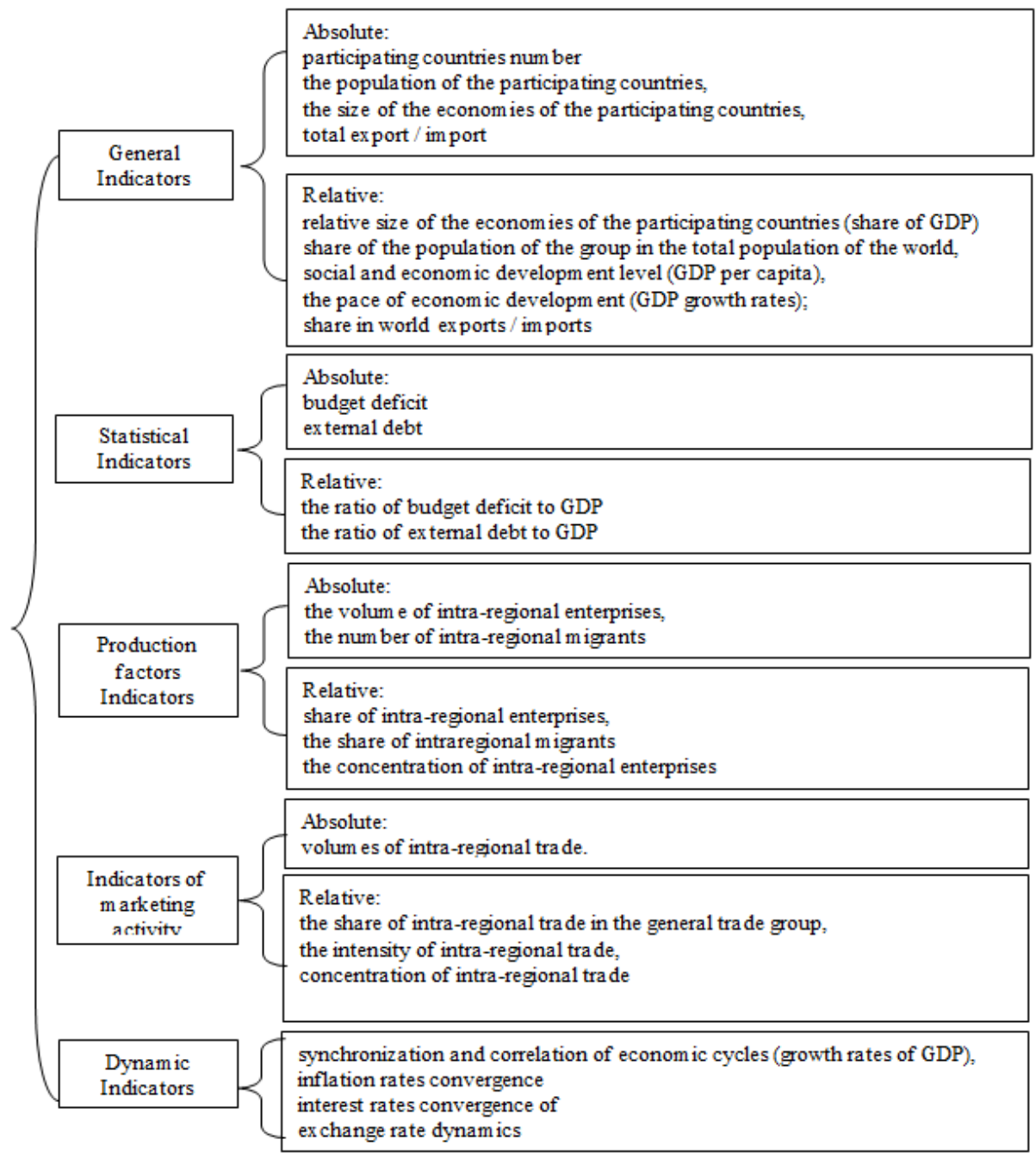

Figure. 3 The basic system of regional economic integration indicators for convergence assessment

Source: is compiled by the author

Such a system of indicators should include absolute and relative indicators measurement of general statistics, estimates factors of production, information on goods and services, 
dynamic indicators, convergence indicators used by enterprises, statistical research domestic and international organizations, World Bank.

Taking into consideration the current approach to the convergence of the World Bank and the features of this study, we will form groups of indicator indicators of convergence (Fig. 4).

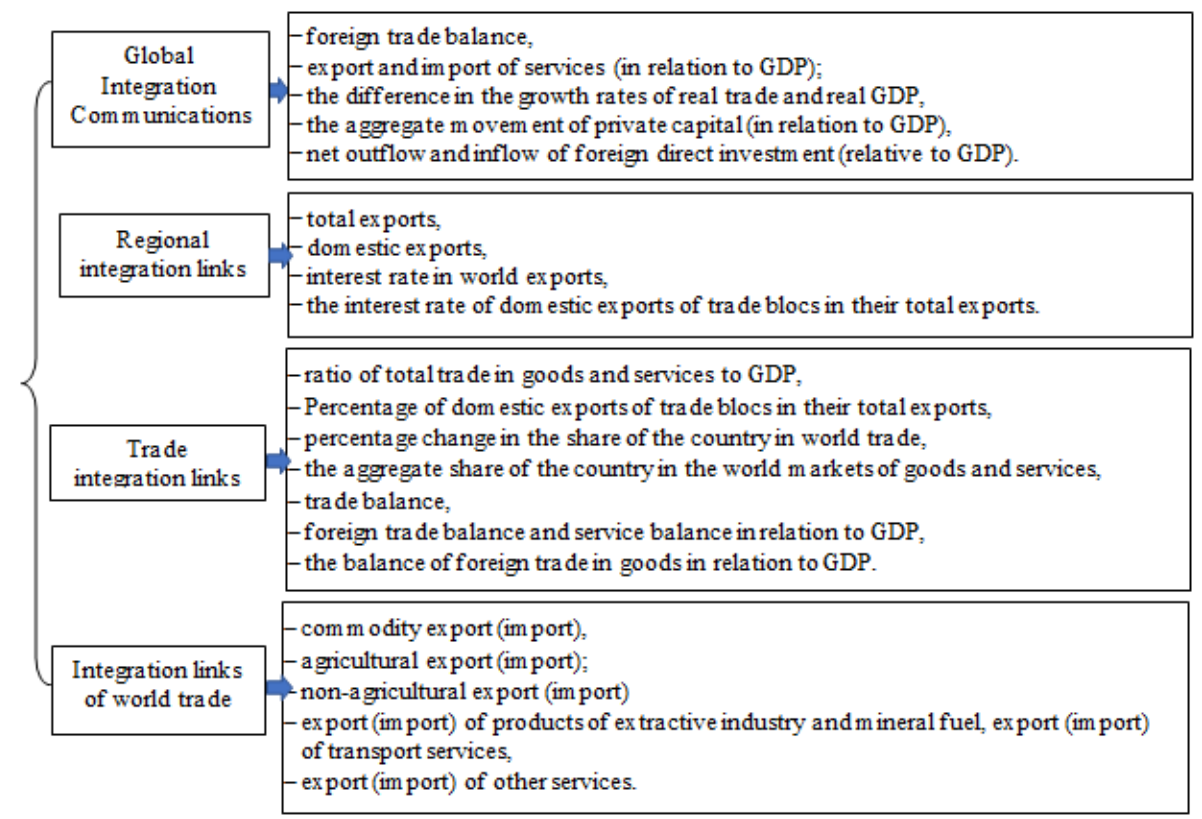

Figure.4 Indicators of Economic Integration for the World Bank to assess the convergence of the investigated structure

Source: is compiled by the author

It is interesting, in our opinion, the classification of convergence indicator groups which is presented by the Eurasian Development Bank (Fig. 5) (1999) [32].

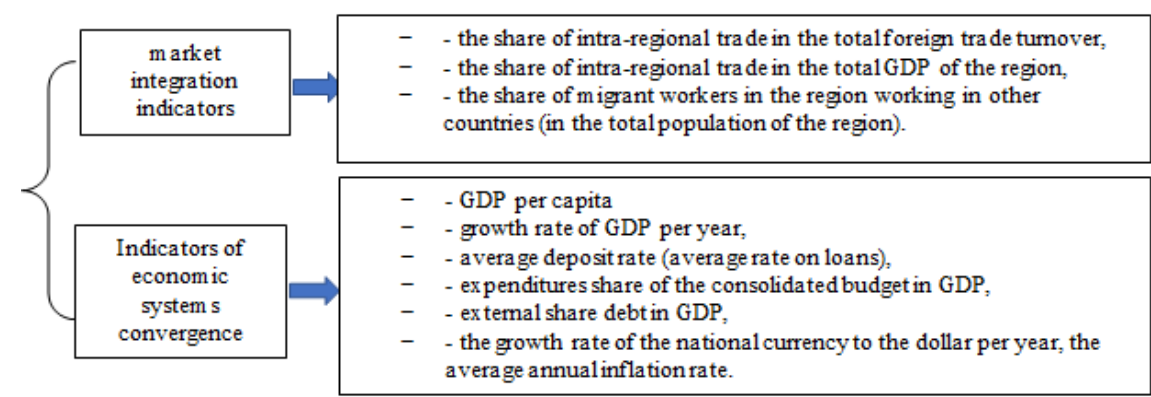

Figure.5 Indicators of Economic Integration by the Eurasian Development Bank to assess investigated structure convergence

Source: is compiled by the author 
Each of the indicators fragments fragmentarily evaluates the degree of convergence and markets of countries similarity, therefore, the calculation and comparison of indicators of different markets, which will be determined by the author when assessing the marketing attractiveness of the new international markets for domestic enterprises, should be conducted dynamically, and for the correctness of the conclusions, it is necessary to make an integral matrix, determining an integral indicator that will reflect the marketing attractiveness of new international markets for enterprise activities.

\section{Methodology}

While applying approaches to the formation of convergence assessment indicators by the World Bank, the Eurasian Development Bank, which provide an opportunity to compare socio-economic indicators of more than 200 markets, determine indicators and indices for assessing their interconnections and offer a consolidated world-wide interactive statistics, which is being developed by world organizations for assessing convergence degree of international markets and their ranking in assessing the marketing attractiveness of new international markets for enterprises activity we have developed a classification of dynamic indicators for assessing the convergence of international markets in determining the marketing attractiveness of new international markets for the enterprise (Chart 1).

\section{Chart 1. Classification estimation indicators of new international markets marketing} attractiveness

\begin{tabular}{|c|c|}
\hline Indicator groups & List of indicators \\
\hline $\begin{array}{l}\text { Indicators of the } \\
\text { international potential } \\
\text { of international trade } \\
\text { integration of the } \\
\text { country }\end{array}$ & $\begin{array}{l}\text { The dynamics of the state of domestic enterprises economic activity by the volume of } \\
\text { production of the main types of products (absolute and relative deviation), } \\
\text { the dynamics of consumption of the main types of products in Ukraine (absolute and relative } \\
\text { deviation), } \\
\text { the dynamics of the market self-sufficiency by products of domestic production (ratio of } \\
\text { volume of gross production to the volume of its consumption \%), } \\
\text { the dynamics export-import geographical structure operations of Ukraine for goods and } \\
\text { services, } \\
\text { dynamics of export operations of Ukraine by separate groups of products, } \\
\text { the dynamics of Ukraine's import operations by product groups, the dynamics of the growth } \\
\text { rate of the product market. }\end{array}$ \\
\hline $\begin{array}{l}\text { Indicators of assessing } \\
\text { economic potential of } \\
\text { international trade } \\
\text { between countries }\end{array}$ & $\begin{array}{l}\text { The size of world gdp, millions of dollars, } \\
\text { the share of gdp of the country in the total world gdp, } \% \text {, } \\
\text { structure of export of goods of countries of the world, mln. dollars, } \% \\
\text { structure of imports of goods of countries of the world, million dollars, } \% \\
\text { share of products in the target industry in the country's gdp, } \%\end{array}$ \\
\hline $\begin{array}{l}\text { Indicators of the } \\
\text { international trade } \\
\text { potential of the target } \\
\text { industry in target } \\
\text { markets }\end{array}$ & $\begin{array}{l}\text { Rate growth of the product market of target countries, } \\
\text { products share in the target industry of target countries in world exports, } \% \text {, } \\
\text { the balance value of trade in the target groups of target countries' markets, million dollars, } \\
\text { annual imports growth of target groups of goods in target markets, } \% \text {, } \\
\text { distance between partner countries, thousand km, } \\
\text { competitors concentration on the target markets of countries, } \% \text {. } \\
\text { the export of products share of the target commodity group in the total volume of export of } \\
\text { the target market, } \% \text {, } \\
\text { share of imports of products of the target product group in the total volume of export of the } \\
\text { target market, } \% \text {, } \\
\text { the country's rating in world exports by target commodity group, } \\
\text { country rating in world imports by target product group, } \\
\text { Annual growth of imports of target products into target countries in terms of value expressed, } \%\end{array}$ \\
\hline
\end{tabular}




\begin{tabular}{|c|c|}
\hline Indicator groups & List of indicators \\
\hline $\begin{array}{l}\text { Indicators of bilateral } \\
\text { trading potential of } \\
\text { partner countries }\end{array}$ & $\begin{array}{l}\text { balance of trade balance of the partner country with Ukraine by the target group of goods, } \\
\text { million dollars, } \\
\text { the volume of Ukraine's exports by the target product group to the partner country, million } \\
\text { dollars, } \\
\text { the share of imports from Ukraine from the partner country in the total import of the target } \\
\text { group of goods, } \% \text {, } \\
\text { the share of imports of the largest competitors of Ukraine in the total import of the partner } \\
\text { country by the target group of goods, } \% \\
\text { annual growth of imports into the partner country of the target group of goods from Ukraine } \\
\text { in value terms, } \% \text {. }\end{array}$ \\
\hline \multirow{11}{*}{$\begin{array}{l}\text { Indicators } \\
\text { attractiveness business } \\
\text { environment of the } \\
\text { target countries }\end{array}$} & Main economic indicators \\
\hline & $\begin{array}{l}\text { economic growth, } \% \text {, } \\
\text { GDP, billion dollars, } \\
\text { Per capita GDP, per purchasing power parity, thousand dollars, } \\
\text { Human Development Index, } \\
\text { inflation index, } \\
\text { household consumption, } \% \\
\text { household consumption, thousand dollars, } \\
\text { saving, } \% \text { of GDP. }\end{array}$ \\
\hline & $\begin{array}{l}\text { Taxes } \\
\text { commercial tax rate, } \%, \\
\text { taxes on international trade, } \%,\end{array}$ \\
\hline & $\begin{array}{l}\text { Management and political system } \\
\text { government efficiency factor, } \\
\text { coefficient of corruption control, } \\
\text { coefficient of quality of legislative regulation, } \\
\text { index of political stability. } \\
\end{array}$ \\
\hline & $\begin{array}{l}\text { Economic freedom } \\
\text { freedom index of business, points, } \\
\text { freedom index of trade, points. } \\
\end{array}$ \\
\hline & $\begin{array}{l}\text { Globalization } \\
\text { economic globalization, } \%\end{array}$ \\
\hline & $\begin{array}{l}\text { International Trade Conditions Trading Conditions Index, } \% \text {, } \\
\text { openness of trade (quotas), } \% \\
\text { Trust Index (FDI) of FDI inflows, } \\
\text { emissions of carbon dioxide CO2 per capita, } \mathrm{m} / \mathrm{t} \text {. }\end{array}$ \\
\hline & $\begin{array}{l}\text { Industry statistics } \\
\text { productivity of agriculture, thousand dollars }\end{array}$ \\
\hline & Innovations \\
\hline & \begin{tabular}{|l|} 
Insurance risk \\
risk ratio of transactions
\end{tabular} \\
\hline & $\begin{array}{l}\text { Work force and education } \\
\text { unemployment rate, } \%, \\
\text { literacy rate, } \% \text {, } \\
\text { percentage of population completing elementary school, } \% \text {, } \\
\text { share of the population who studied at universities, } \%, \\
\text { average net financial standing per capita, thousand dollars, } \\
\text { population, million people }\end{array}$ \\
\hline
\end{tabular}

Source: is compiled by the author

Consequently, the efficiency of the process of convergence of international markets depends on the existing potential differences, the rates of development of markets of the countries under study and the chances of overcoming the gap in their main indicators. When expert evaluation of indicators of the degree of convergence of international markets, it is necessary to select the markets of foreign countries, which will have the indicators as close as possible to the Ukrainian economy, the result of evaluation will 
allow us to draw conclusions about the marketing opportunities of domestic enterprises in the conditions of release of goods to the markets of these countries.

\section{Results of the Study}

According to the results of international markets study (Kovin'ko O. M., 2016) [16, 35], we will select segments for the effective sale of the domestic agricultural products of the commodity groups "10 Grain Cultures", "12 Fats and oils", "15 Seeds and Fruits". Such a choice can be made by analyzing the dynamic indicators that determine the bilateral trading potential of the partner countries (Chart 1).

Trade balance of the markets of the countries dynamics, the volumes of export and import of products of the commodity group by country, export and import products share of the product group in the total export of the country, markets ratings in world exports and imports, by this product group, rates growth of imports are expressed in terms of value sales volumes, balance of trade balance of the partner market with Ukraine for the given group of goods, imports volume by this commodity group from Ukraine, import share from Ukraine, import share of the largest competitor Ukraine in this commodity market, rates growth of imports of the commodity group in value terms from Ukraine, which determine the convergence of marketing attractiveness of the new international markets by the group of goods " 10 Grain Cultures" is presented in Chart. 2 (Kovin'ko O. M., 2016, Trade Statistics for the Development of International Business, 2015-2016) [16, 35].

Chart 2. Indicators dynamics, which determine marketing attractiveness convergence of new international markets by the group of goods "15 Fats and oils", 2018.

\begin{tabular}{|l|c|c|c|c|c|c|c|c|c|c|c|}
\hline Indicators & Austria & Belgium & Greece & Ireland & Italy & China & Netherlands & Germany & Switzerland & Japan \\
\hline 1 & 2 & 3 & 4 & 5 & 6 & 7 & 8 & 9 & 10 & 11 \\
\hline $\begin{array}{l}\text { Balance of the country, } \\
\text { million dollars in this group }\end{array}$ & $-234,77$ & $-190,03$ & 523,1 & $-363,13$ & $-1803,3$ & $-7516,97$ & $-703,8$ & $-1018,37$ & $-296,3$ & $-1255,9$ \\
\hline $\begin{array}{l}\text { Exports of products of the } \\
\text { commodity group, mln }\end{array}$ & 293,37 & 1878,1 & 851,8 & 81,2 & 2412,3 & 1092,6 & 4973,56 & 2858,2 & 77,6 & 231,2 \\
\hline $\begin{array}{l}\text { Share of exports of } \\
\text { products of the product } \\
\text { group in the total volume of } \\
\text { export of the country, } \%\end{array}$ & 0,3 & 2 & 0,9 & 0,1 & 2,6 & 1,2 & 5,3 & 3,1 & 0,1 & 0,2 \\
\hline $\begin{array}{l}\text { Volume of imports of } \\
\text { products of the commodity } \\
\text { group, mln }\end{array}$ & 528,1 & 2068,2 & 328,7 & 444,34 & 4215,6 & 8609,6 & 5677,4 & 4252,5 & 373,8 & 1487,2 \\
\hline $\begin{array}{l}\text { Share products of imports } \\
\text { of product group in the } \\
\text { total import of the } \\
\text { country, } \%\end{array}$ & 0,5 & 2,1 & 0,3 & 0,5 & 4,3 & 8,9 & 5,9 & 4 & 0,4 \\
\hline $\begin{array}{l}\text { Country rating in world } \\
\text { exports, for this product } \\
\text { group }\end{array}$ & 41 & 12 & 20 & 71 & 11 & 17 & 4 & 9 & 7,5 \\
\hline $\begin{array}{l}\text { Country rating in world } \\
\text { imports, by this product } \\
\text { group }\end{array}$ & 27 & 10 & 52 & 45 & 5 & 2 & 4 & 6 & 47 \\
\hline $\begin{array}{l}\text { Annual growth (or drop) of } \\
\text { imports between 2017-2018, } \\
\text { by this commodity group, } \%\end{array}$ & 1 & 0 & -6 & -20 & -8 & 4 & -3 & -13 & 5 \\
\hline
\end{tabular}




\begin{tabular}{|c|c|c|c|c|c|c|c|c|c|c|}
\hline Indicators & Austria & Belgium & Greece & Ireland & Italy & China & Netherlands & Germany & Switzerland & Japan \\
\hline 1 & 2 & 3 & 4 & 5 & 6 & 7 & 8 & 9 & 10 & 11 \\
\hline $\begin{array}{l}\text { Balance of the country's } \\
\text { trade balance with Ukraine } \\
\text { for the given group of } \\
\text { goods, mln }\end{array}$ & 5,03 & 10,64 & 2,5 & 0,4 & 232,5 & 425,5 & 252,72 & 10,96 & $-0,41$ & 0,59 \\
\hline $\begin{array}{l}\text { Volume of imports by this } \\
\text { commodity group from } \\
\text { Ukraine, mln }\end{array}$ & 5,18 & 14,5 & 4,7 & 0,3 & 236,9 & 426,1 & 258,2 & 14,1 & 0,6 & 0,6 \\
\hline $\begin{array}{l}\text { The share of imports from } \\
\text { Ukraine, } \%\end{array}$ & 1 & 0 & 2 & 0 & 6 & 5 & 4 & 2 & 0 & 0 \\
\hline $\begin{array}{l}\text { Annual growth of imports } \\
\text { from Ukraine between } \\
2014-2018 \text { for this product } \\
\text { group, } \%\end{array}$ & 0 & -51 & 18 & 0 & 13 & -2 & 20 & 32 & 150 & 46 \\
\hline
\end{tabular}

Source: Formed by (Global Economy, Trade Statistics for International Business Development) [5, 6, 29]

We can conclude that a passive trade balance value of all markets, except for Greece, evidence of consumer demand for the product group "15 Fats and oils". Positive balance of trading balance of the Greek market, and the lowest value of this indicator markets, Italy, China, Germany, Japan shows a decline in demand for the commodity group "15 Fats and oils". The negative trade balance by group of products "15 Fats and oils" markets of Austria, Belgium, Ireland, the Netherlands and Switzerland means that there is demand for fats and oils.

According to the analysis of imports and exports of the commodity group "15 Fats and oils" in 2018 unable to estimate the coverage ratio of imports by exports: the value of the coefficient on the market Belgium is 0.91, the Netherlands - 0,88 (closer to 1), the Greek market, at 2.59 (greater than 1), meaning that these markets are not promising for Ukrainian agricultural enterprises (Fig. 6).

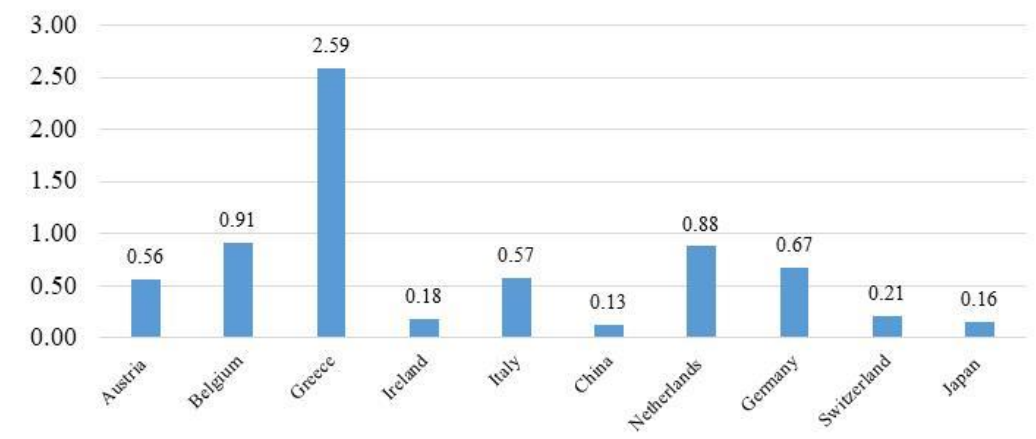

Figure.6. Dynamics of the coefficient of imports coverage by agrarian products export of the commodity group "15 Fats and oils", 2018

Source: compiled by (for Global Economy, Trade Statistics for International Business Development) [5, 6, 29]

The value of the coverage ratio of imports by exports in the markets of Austria, Ireland, Italy, China, Germany, Switzerland and Japan ranges from 0 to 0.67 , which indicates dependence on imports of these markets from the commodity group "15 Fats and oils", unsaturated markets for fats and oil of appropriate quality, hence the need for imports of this product group. Consequently, foreign markets of Austria, Ireland, Italy, China, 
Germany, Switzerland and Japan are promising for the domestic agricultural enterprises in the conditions of international diversification.

For 2018, there was annual growth of import of commodity group "15 Fats and oils" only in the market of Austria and China, all other markets due to higher prices for these goods, negative import growth rate (Fig. 7).

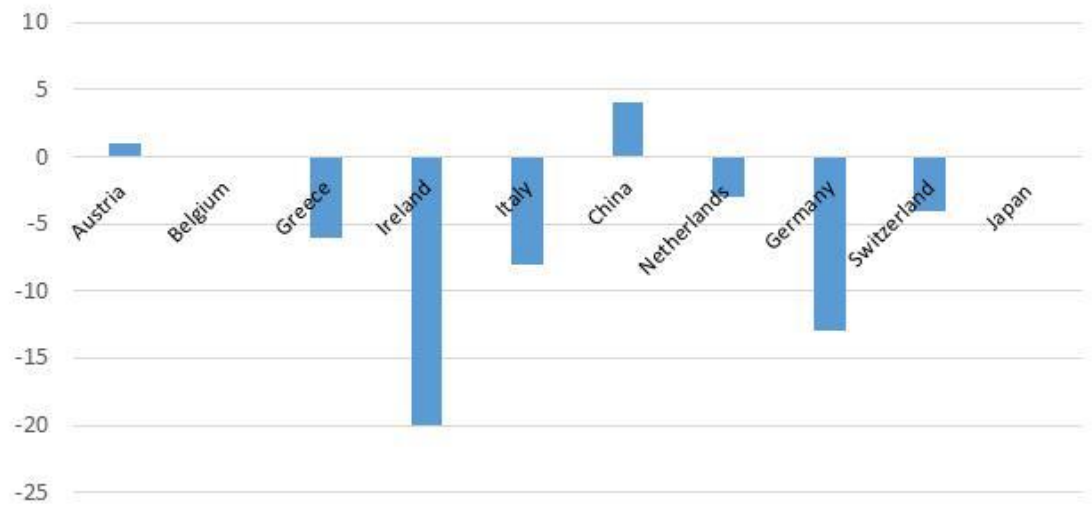

Figure.7. Estimation of annual growth of imports between 2018 by commodity group "15 Fats and oils",\%

Source: is compiled by (for Global Economy, Trade Statistics for International Business Development) [5, 6, 29]

Annual growth of exports from Ukraine in this group of goods in the markets of Greece, Italy, the Netherlands, Germany, Switzerland, and Japan in 2018 had a positive value. This means that, moving in step with the times, Ukrainian agricultural enterprises have already activated their international activities and increased the sales volumes of the group "15 Fats and oils" in international markets. In 2018 in the markets of Austria, Belgium, Ireland and China-the volume of import from Ukraine decreased significantly (Fig. 8).

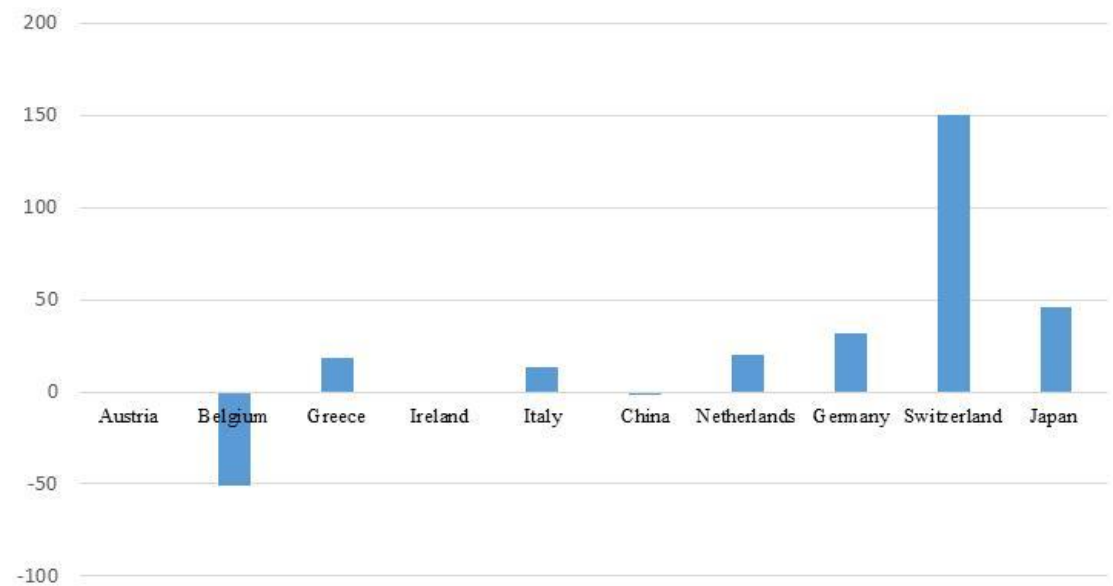

Figure.8 Dynamics of consumption of fats and oilswith Ukraine by importing partners, 2018,\%

Source: is compiled by (for Global Economy, Trade Statistics for International Business Development) [5, 6, 29] 
Dynamics of consumption of grain crops from Ukraine partners-importers in 2018 indicates the prospects of expansion of these markets, sales of Ukrainian agricultural enterprises to the new markets of Netherlands, Germany, Switzerland, Japan (the global economy, trade Statistics for international business development) [5, 6, 29].

Dynamics of imports of the investigated markets allows to draw the following conclusions: in 2018 the largest share of exports of commodity group "15 Fats and oils" Ukraine was in the markets of Italy, China, Netherlands, Germany, Greece- 6\%, 5\%, $4 \%, 2 \%, 2 \%$ respectively.

Thus, Ukrainian companies engaged in the sale of commodity group "15 Fats and oils", there are development prospects in the markets of Italy, China, the Netherlands and the expansion potential of the share markets of Austria, Belgium, Ireland, and Switzerland. Given that the trade balance of the world for a group of "15 Fats and oils" in 2018 shows a negative result we believe that the domestic agricultural enterprises need to systematically explore the prospects of entering international markets, namely markets: Italy, China with the goal of international diversification on them.

While choosing methods for assessing the attractiveness of international markets, it is important that agribusinesses cannot be guided by dogmatic, universal solutions in the context of international diversification of business, because this process requires creativity aimed at satisfying the requirements of a particular consumer in a particular market and period of time. We will assess the degree of convergence of certain international markets, according to the indicators of the attractiveness of the business environment of the target markets (Chart 1), which is important to consider in order to further develop a marketing strategy for international diversification of business of agricultural enterprises (Chart 3).

Chart 3. Estimation of Convergence of New International Markets for Domestic Enterprises under the Conditions of International Diversification, 2018 (10.10.2019) [5, 6]

\begin{tabular}{|c|c|c|c|c|c|c|c|}
\hline $\begin{array}{l}\text { Factor / } \\
\text { foreign market }\end{array}$ & Year & 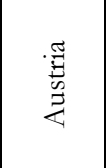 & 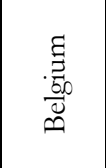 & $\begin{array}{l}\vec{\Xi} \\
\stackrel{\vec{J}}{ \pm}\end{array}$ & 狊 & 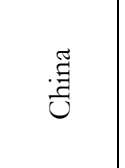 & 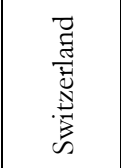 \\
\hline \multicolumn{8}{|l|}{ Main economic indicators } \\
\hline Economic growth, $\%$ & 2018 & 2,73 & 1,44 & 8,17 & 0,86 & 6,60 & 2,54 \\
\hline GDP at current prices, billion dollars & 2018 & 455,74 & 531,8 & 382,5 & 2073,9 & 13608,15 & 705,5 \\
\hline $\begin{array}{l}\text { GDP per capita by purchasing power parity, } \\
\text { thousand dollars / person }\end{array}$ & 2018 & 46473,3 & 43217,9 & 70855,3 & 35739,0 & 16186,8 & 59019,21 \\
\hline Inflation rate (by consumer price index) & 2018 & 1,53 & 0,8 & 0,69 & 0,29 & 2,51 & 0,15 \\
\hline Household consumption, $\%$ & 2018 & 51,66 & 51,08 & 30,87 & 60,72 & 38,74 & 52,92 \\
\hline $\begin{array}{l}\text { Household consumption } \\
\text { billion dollars }\end{array}$ & 2018 & 235,45 & 271,62 & 116,05 & 1259,32 & 4700,4 & 373,36 \\
\hline \multicolumn{8}{|l|}{ International trade conditions } \\
\hline Trading Commodity Index, $\%$ & 2017 & 87,30 & 95,97 & 91,03 & 102,61 & 87,29 & 110,18 \\
\hline $\begin{array}{l}\text { Trust index } \\
\text { (or foreign direct investment) }\end{array}$ & 2019 & 1,50 & 1,54 & 1,52 & 1,67 & 1,72 & 1,59 \\
\hline \multicolumn{8}{|l|}{ Agriculture } \\
\hline The share of agriculture in GDP, $\%$ & 2018 & 1,17 & 0,69 & 0,92 & 1,88 & 7,19 & 0,65 \\
\hline Value added in agriculture, billion of dollars & 2018 & 5,35 & 3,65 & 4,88 & 39,03 & 978,45 & 4,59 \\
\hline
\end{tabular}




\begin{tabular}{|l|c|c|c|c|c|c|c|}
\hline Innovations & 2019 & 50,90 & 50,20 & 56,1 & 46,30 & 54,8 & 67,2 \\
\hline Innovation Index & 2018 & 51,50 & 57,70 & 26,0 & 53,1 & 64,9 & 28,8 \\
\hline Taxes & 2017 & 1,46 & 1,18 & 1,29 & 0,5 & 0,42 & 2,06 \\
\hline Commercial tax rate, \% & 2018 & 1,53 & 1,5 & 1,55 & 0,19 & $-0,27$ & 1,99 \\
\hline Management and political system & 2017 & 1,04 & 0,42 & 1,02 & 0,24 & $-0,25$ & 1,21 \\
\hline Government Effectiveness & 2019 & 75 & 78 & 83 & 72 & 56 & 75 \\
\hline Coefficient of corruption control & 2019 & 86 & 86 & 86 & 86 & 73 & 87 \\
\hline Political Stability Index & 7019 & 1 & 1 & 1 & 1 & 1 & 1 \\
\hline Economic freedom & 2019 & & \\
\hline Business Freedom Index, points & 2019 & 7,25 & 6,92 & 7,02 & 6,22 & 5,19 & 7,48 \\
\hline Trade Freedom Index, scores
\end{tabular}

Source: compiled by the author for (Global Economy, Trade Statistics for the Development of International Business) [5, 6, 29]

Economic growth is the annual GDP growth at market prices, which is the sum of value added of all resident producers in the economy and any product tax minus any subsidies that are not included in the value of gross value added products. We can conclude that the greatest importance of economic growth in 2018 among the studied countries was shown by the markets of Ireland and China, in all other growth is less than the average world index $-3,31 \%$.

The largest amount of real GDP in the price of the buyer in 2018 was recorded in China and Italy, while other markets had a relatively smaller GDP (Global Economy) [6]. One of the important indicators is per capita GDP per purchasing power parity (PPP), which is a measure of per capita output in dollars per PPP. The level of real GDP per capita in the studied markets allows us to compare different international markets, to determine to what category they belong - developed or developing. GDP is an indicator for less developed markets, as it compensates for the weakness of local currency in world markets. Among the studied markets, the GDP per capita PPP higher than the international average in 2018 (19558,2 thousand dollars) in all markets except China, but in this segment leaders are the markets of Ireland and Switzerland.

An important indicator is the level of inflation (by the consumer price index), which is measured by the consumer price index and reflects the annual percentage change in prices for consumers for the purchase of goods and services. All investigated markets, in addition to the China market, showed the inflation rate (by consumer price index) below $1.5 \%$, then we can argue that these markets are promising from the point of view of effective convergent terms of cooperation, but it is necessary to continuously control the level of inflation (by the consumer price index) in the Chinese markets, because of its fluctuations in these markets. Only in the markets of Belgium, Switzerland and Italy there was a slight increase in CPI inflation (consumer price index), and therefore these markets may be promising for domestic agrarian enterprises, as the most stable markets (Global Economy) [6].

It is worthwhile paying attention to such an indicator as an index of terms of trade, an increase which is indicative of the welfare of the nation. Calculated as a percentage of the 
index of export value of a unit of goods to the index of unit value of imports, measured by the ratio to the base year 2000 . If the trading conditions index $T=1$, then this means that the export and import prices are the same and the terms of trade remain unchanged. If $\mathrm{T}$ is more than 1 , then this means that you can purchase more imported goods for each unit of the exported product. As more imports become possible instead of the former, the welfare of the country will increase. Thus the terms of trade have improved compared to the base period. If the trading conditions index $\mathrm{T}<1$, then this means that for each unit of the exported product, less and less imported goods can be purchased. As a smaller volume of imports becomes possible instead of the former, the welfare of the country is shrinking. In this way, trade conditions deteriorated, the world average in 2018 was 114.13. The investigated international markets showed close to an average of more than 1, indicating that the conditions for trade on the markets of Austria, Belgium, Ireland, Italy, China, Switzerland have been satisfactorily successful, as consumers' wellbeing of these markets is growing and there are improved trade conditions.

There is a correlation between the consumer price index and the trust index (FDI foreign direct investment), as the inflow of foreign direct investment into the country's market is possible only at a low inflation rate. In this study, the FDI inflow rate was calculated as the weighted average by the number of high, medium and low responses to the question of the probability of direct investment in the market among investors in the world. Higher index values point to more attractive investment goals. At the level of the average world value in 2018 - 1.64 world experts showed confidence in the markets of Belgium, Italy, China. With the fall in prices in Ireland, there was concern for world investors about doing business in these markets (Global Economy) [6].

Added value per one employee of agriculture is a measure of his productivity, and in the long run it will allow making decisions on the formation of approaches to designing international diversified structures and the optimal way of entering international markets. In all the markets studied, except for Italy and China, agricultural productivity is above the world average (for 2018 - 21,6 thousand dollars per person), but none of the markets has reached the maximum value, which testifies to the need for the market in the development of agrarian business, respectively, favorable prospects for the exit on these markets of Ukrainian agricultural enterprises with the creation of their own business model at each of them (Global Economy) [6].

The next indicator, which includes two sub-indexes, is a global index of innovation, which, on the one hand, is based on five main components: institutions, human capital and research, infrastructure, and the level of business development; on the other - for two: knowledge and technology of inventions and creative activities. The development and implementation of innovations is the basis for increasing the efficiency of the economy of foreign markets, namely: growth of production volumes, improvement of living standards, access to new markets. It is important that the index of innovations in the studied markets is high, as it will allow domestic enterprises to apply marketing innovative technologies during the formation of marketing strategies for entering the foreign markets, the formation of the range of products. The largest global index of innovations - 67.2 points in 2019, among other studied foreign markets, the active indicator in 2019 was in the markets of Austria - 50,9, Belgium -50.20, Ireland - 56.1, China is 54.8 and Switzerland - 67,2 and respectively (Global Economy) [6]. The least 
attractive in terms of international business diversification remains Italy market.

Ukrainian enterprises willingness to expand sales markets and to win new ones, on which conditions of operation will be better, should result in the indicator "Commercial tax rate". The average worldwide value of the commercial tax rate in 2018 was $40.56 \%$.

In the studied markets, the value of the overall indicator was lower than the average in Ireland and Switzerland (Global Economy) [6]. All other markets are more attractive to Ukrainian agrarians, as high tax rates can lead to the disappearance of foreign agribusiness markets.

Researches at one and the same time prove that the output of domestic enterprises in the external market is impossible without a preliminary study of the international marketing environment, the whole set of factors, which will depend on the effective functioning of the firm in a foreign country. The study of political and legal factors was carried out by comparing the indicators "Government efficiency coefficient", "The coefficient of corruption control", "Quality of legislative regulation coefficient ", "Index of political stability".

Government effectiveness reflects perceptions of the quality of public services, the quality of public service and the level of its independence from political pressure, the quality of policy formulation and implementation, as well as the government's confidence in such policies. Corruption control reflects the perception of the level at which state power manages for personal gain, including the small and grandiose forms of corruption, as well as the capture of the state by elites and private interests, and their evaluation helps to determine the government's ability to develop and implement sound policies and regulations, which will promote business development through international diversification.

These figures are complex, since they are based on several other indicators from a variety of sources, including the Economist Intelligence Unit, the World Economic Forum, etc. The basic indicators reflect the probability of a systemic transfer of state power, armed conflicts, violent demonstrations, social unrest, international tensions, terrorism, as well as ethnic, religious or regional conflicts. The general index methodology is stored consistently, so its value can be compared with time. Comparing selected indicators of the political environment, we can conclude that the markets of Austria, Belgium, Ireland, Italy and Switzerland are clearly promising for Ukrainian agribusiness. Since the values of all indicators are close to the maximum global value and significantly outpacing the average world value.

The next important indicators in assessing the prospects of entering the foreign market are freedom of business, freedom of trade, which is not only an external background, but a determining factor in the development of national economies, which directly or indirectly affects the behavior of producers and consumers in the domestic market. The assessment of business freedom is based on ten indicators, using data from the Doing Business World Bank study:

- business procedures (number), time (days), cost ( $\%$ of per capita income), as well as minimum capital (\% of per capita income);

- obtaining a license-procedure (number), time (days), and cost ( $\%$ of income per capita); - business closure (years), cost ( $\%$ of average per capita income), and recovery rate (dollars per dollar) (Global Economy) [6]. 
Trade freedom assessment is calculated on the basis of two indicators: the tradeweighted average rate of tariffs and non-tariff barriers (including quantity, price, regulatory, customs and investment restrictions, direct intervention of the government). In all the markets studied, apart from China, the indexes of the Index of Freedom of Business, the Index of Freedom of Trade, reached the highest values than in other markets and more than the world average, so it can be argued that the markets of Austria, Belgium, Ireland, Italy, Switzerland are promising for international diversification of business of domestic agrarian enterprises.

An important stage in the study is the assessment of the risks of conducting special monetary operations, based on contractual work and the implementation of projects with long-term implementation. Political risk covers the risks of currency shortfalls, wars, revolutions, natural disasters. Government market actions are divided into seven categories (from 1 - low risk to 7 - high risk), reflecting the intensity of political risk. All markets are attractive for domestic agrarian enterprises activity.

The OECD countries are the index of better life, which is an interactive tool that allows you to see the situation in the countries, the importance of identifying 11 aspects that improve the lives of consumers: living conditions, income, society, education, ecology, civil rights, health, satisfaction, safety, work / leisure. The evaluation of each aspect is carried out according to 4 indicators: the aspect of "Work" is evaluated in four separate indicators: employment rate, personal income, long-term unemployment level and employment guarantee.

Taking into account that the average world index of a better life per capita index in 2019 was 5,42, then the markets of Ausria, Belgium, Ireland and Switzerland are attractive for domestic enterprises, as in these countries a high level of quality of life of the population, and hence a high culture of consumption of products of agrarian production.

Analyzing the information provided by the World Bank, the Eurasian Development Bank, and developing indicators for assessing the convergence identified degree in this market study, we will assess the indicators that will lead to the spread of convergence in the future, that is, the similarities of market entry conditions in order to carry out activities that will attract more the number of markets to international activity (Chart 4).

Ranking has been done by a group of ten experts on the basis of the summation of ranks pre-defined as potential markets in the 5 scales. The average, largest and smallest global values of each indicator (1-2 - minimum value, 3-4 - average value, 5 - maximum value) were taken into account when compiling the evaluation table, the summation method determined the overall index of each market, the maximum value of which is evidenced by more favorable conditions for the output of domestic enterprises on it (Kovin'ko O. M., 2017) [16, 35]. 
Chatr 4. Rethinking international markets based on the method of summing up the ranks of convergence indicators among investigated markets, 2018 (10.10.2019)

\begin{tabular}{|c|c|c|c|c|c|c|}
\hline $\begin{array}{l}\text { Factor / } \\
\text { foreign market }\end{array}$ & 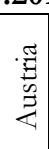 & 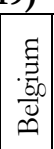 & $\begin{array}{l}\vec{\Xi} \\
\vec{\Xi} \\
\stackrel{\Xi}{\Xi} \\
\Xi\end{array}$ & 氙 & 茎 & 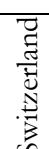 \\
\hline Economic growth, $\%$ & 2 & 2 & 5 & 2 & 4 & 2 \\
\hline GDP at current prices, billion dollars & 2 & 2 & 2 & 3 & 4 & 2 \\
\hline GDP per capita by purchasing power parity, thousand dollars / person & 4 & 4 & 5 & 4 & 3 & 4 \\
\hline Inflation rate (by consumer price index) & 5 & 5 & 5 & 5 & 4 & 5 \\
\hline Household consumption, $\%$ & 5 & 5 & 3 & 5 & 4 & 4 \\
\hline $\begin{array}{l}\text { Household consumption } \\
\text { billion dollars }\end{array}$ & 4 & 4 & 3 & 5 & 5 & 2 \\
\hline Trading Commodity Index, $\%$ & 2 & 2 & 2 & 2 & 2 & 3 \\
\hline Trust index, (or foreign direct investment) & 2 & 2 & 2 & 4 & 4 & 3 \\
\hline The share of agriculture in GDP, $\%$ & 4 & 4 & 4 & 4 & 3 & 3 \\
\hline Value added in agriculture, billion of dollars & 5 & 5 & 5 & 2 & 1 & 5 \\
\hline Innovation Index & 4 & 4 & 4 & 4 & 4 & 4 \\
\hline Commercial tax rate, $\%$ & 2 & 2 & 4 & 2 & 2 & 4 \\
\hline Government Effectiveness & 4 & 4 & 4 & 4 & 4 & 5 \\
\hline Coefficient of corruption control & 4 & 4 & 4 & 4 & 2 & 5 \\
\hline Political Stability Index & 4 & 4 & 4 & 4 & 2 & 5 \\
\hline Business Freedom Index, points & 4 & 4 & 5 & 4 & 3 & 4 \\
\hline Trade Freedom Index, scores & 4 & 4 & 4 & 4 & 3 & 4 \\
\hline Transaction risk coefficient & 5 & 5 & 5 & 5 & 5 & 5 \\
\hline Index life quality of the population & 5 & 5 & 5 & 4 & 4 & 5 \\
\hline Total & 71 & 71 & 75 & 71 & 63 & 74 \\
\hline
\end{tabular}

Source: is compiled by (Global Economy, Organization for Economic Cooperation and Development, World Economy, World Finance, World Markets) [5, 6, 10, 11, 12, 18, 28, 29$].$

\section{Discussion on Future Prospects}

As a result of the comprehensive study by the summation of the ranks based on the above indicators, it was found that the markets of Ireland, Switzerland have demonstrated favorable conditions for doing business on them, indicating a significant convergence that is a prerequisite for the release of domestic agricultural products enterprises on the markets of these countries. That is, the application of this approach made it possible to develop a target portfolio for further targeting the implementation of an international diversification strategy by Ukrainian agrarian enterprises (Chart 5).

Chart 5. Marketing direction definition of business of Ukrainian agrarians in conditions of international diversification (Kovin'ko O. M., 2017) [16, 35]

Product group name "15 Fats and oils"

\begin{tabular}{|l|l|}
\hline 2015-2016 [Kovin'ko O. M., 2017] & 2018-2019 \\
\hline
\end{tabular}

1. An actual opportunity for domestic enterprises to enter the markets

Austria, Belgium, Italy, China, Netherlands, Austria, Belgium, Italy, China, Netherlands, Germany, France, Switzerland, Japan, Slovakia $\quad$ Germany, France, Switzerland, Japan, Slovakia

2. It is recommended that domestic enterprises study the prospects of entering the markets

\begin{tabular}{|l|l}
\hline Greece, Ireland, China, Switzerland, Japan & Austria, Belgium, Ireland, Italy, China, Netherlands
\end{tabular}

3. Defined markets in which convergent conditions for the goods of domestic agrarian enterprises

\begin{tabular}{|l|l|}
\hline Belgium, Italy, Ireland, Switzerland, Japan & Ireland, Switzerland \\
\hline
\end{tabular}

Source: is compiled by the author 
Markets of Austria, Belgium, Italy, will be promising for domestic enterprises under the condition of overcoming a significant lead in their main indicators, namely the markets of Austria, Belgium and Italy show a low rate of economic growth, the index of terms of trade and confidence index (FDI) inflows of foreign direct investment, high commercial tax rate; in addition, the Italian market has not a stable business climate for exporters of agricultural products and low quality of life.

\section{Conclusion}

It is proved that the estimation of marketing attractiveness of international markets for agrarian enterprises of Ukraine can be carried out by analyzing the system of indicators, criteria and factors that they should take into account while determining new international markets for making a decision on realization of their economic interests on them.

As the assessment of the attractiveness result of the markets of Австріi, Belgium, Ireland, Italy, China, Switzerland for Ukrainian agrarian enterprises for the purpose of agricultural products, it was determined that the markets of Ireland, Switzerland are convergent for the international activity of domestic enterprises.

Of course, there will be obvious essential problems of adaptation of domestic agrarian products to the quality standards of these countries, the risks of misunderstanding and non-acceptance of agricultural products of certain species, unreasonable costs for forming the loyalty of consumers of international markets and also the risks of reducing demand for agricultural products, so Ukrainian agrarian enterprises must "think globally, but act locally".

In order to enter the markets of Ireland, Switzerland and without losing competitive advantage, companies have to combine different approaches - standardization (priority for indicators of efficiency of their own production) and adaptation (marketing of specific needs of different markets).

\section{Acknowledgment}

The author would like to thank Pavlenko A. F. of the KNEU named after Vadym Hetman for their help and support in making this work possible. This work might not have been possible had it not been for the efforts of the prior European journal of sustainable development. Their work still lives on to some degree within European journal of sustainable development.

\section{References}

Balcerovich, L. (2015), About reforms in Poland and Ukraine. URL: http://aillarionov.livejournal.com/784039.html.

Bogomolov, O. (2012), The economy needs reliable indicators. Economic strategies. №1. P.12-17. (Russia). Boychuk, I, Music, O. (2010), Internet in the Marketing, Kyiv, Center for Educational Literature, (Ukraine). Bulatova, O. (2010), Methodological approaches to the study of trade and economic component of regional economic processes. Problems and prospects of cooperation between the countries of South- 
Eastern Europe within the framework of the Black Sea Economic Cooperation and GUAM, Istanbul-Donetsk, DonNU, (Russian).

World Trade Organization (2015-2016), URL: https://www.wto.org/english/ res e/statis e/its2015 e/its2015 e.pdf

Global economy (2013-2017), URL: http://www.theglobaleconomy.com/rankings/happiness/

Grigorets, T. (2005) Realization of foreign economic interests of the EU in the process of economic convergence. URL: http://www.niisp.gov.ua/vydanna/panorama/issue.php?s=gpgs2 \&issue $=20053$

World Bank Group (2013-2017), URL: http://wdi.worldbank.org/table/

Grzegorz, Kolodko, V. (2005), From shock to therapy. URL: http://www.ji.lviv.ua/jilibrary/kolodko/kolodko-4.htm.

Department of Agriculture of the United States. Economic Research Service, (2015-2017), URL: http://www.ers.usda.gov/data-products/chart-gallery/detail.aspx

AGRICISTRADE Research Project. Agriculture and trade development of the EU's eastern neighbors (2015), URL: $\quad$ http://www.agricistrade.eu/wp-content/uploads/2015/06 $\angle$ Agricistrade Ukraine.pdf

Worldwide Governance Indicators (RGO) draft consolidated reports and individual management indicators for 215 economies for the period 1996-2014, (2017), URL: http://info.worldbank.org/governance/wgi/index.aspx\#home.

Kovin'ko, O. (2016), Practical aspects of business activity of agrarian enterprises in conditions of international diversification: estimation of attractiveness of international markets. Strategy of economic development of Ukraine. No. 39. P. 99-107.

Kovin'ko, O., Pyatkevsky, V. (2016), Methodological bases of development of marketing conception of enterprise development. Eastern Europe: Economics, Business and Management, No. 2, URL: http://easterneurope-ebm.in.ua/journal/2 2016/32.pdf.

Kovin'ko, O. (2016), Convergence as a prerequisite for the release of goods into new markets. Socio-political, economic and bumanitarian dimensions of European integration of Ukraine, Vinnytsia (Ukraine).

Kovin'ko, O. (2017), Marketing in the context of international diversification of business activities. KNEU, Kiev (Ukraine).

Korolchuk, L. (2012), Economic convergence of regions as a prerequisite for deepening the processes of intensifying cooperation. URL: $\underline{\text { http://eforum-lntu.com/assets/files/articles/2012/3/28.pdf }}$

KOF Globalization Index(2017), URL: http://globalization.kof.ethz.ch

Lukyanenko, D., Poruchnik, A., Kolot, A., Stolyarchuk, A. (2011), Resources and models of global economic development. KNEU, Kiev (Ukraine).

Lukyanenko, D., Chuzhikov, V., Vozhnyak, G. (2010), Convergence of Economic Models of Poland and Ukraine, KNEU, Kiev (Ukraine).

Malhotra, N. (2002), Marketing research and effective analysis of statistical data. LLC "TID" DS ", Kiev (Ukraine).

Mironov, M. (2010), Structural changes in the Ukrainian economy: their necessity and priorities of realization. URL: http://vuzlib.com.ua/articles/book/14370-Strukturn \%D1 \%96 zm \%D1 \%96ni_v

Moiseyeva, N., Goncharova, T., Marina, O., Sedova, O. (2015), Transformation of business in the conditions of market instability. KURS: INFRA M, Moscow (Russia).

National Bank of Ukraine, (2013-2017), URL: www.bank.gov.ua

Nedogreeva, A. (2006), Historical background and strategy of European integration of Ukraine. Foreign Trade: Law and Economy, No. 4. P. 65-68.

Organization of economic cooperation and development, (2014-2016). URL: http://www.oecdbetterlifeindex.org/countries /belgium/

Official site of the State Statistics Service of Ukraine, (1998-2016), URL: http://www.ukrstat.gov.ua/operativ/menu/menu u/nac r.htm.

World economy. World finances. World markets, (2014-2016), URL:

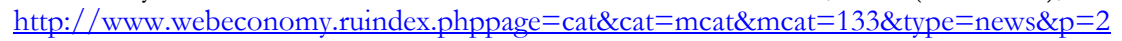

Trade statistics for international business development, (2013-2017), URL: http://www.trademap.org.

Filipenko, A, Budkin, V, Galchinsky. A. (2002), Ukraine and the world economy: interaction at the turn of the millennium, Lybid, Kiev (Ukraine). 
Barro Robert, J., Xavier Sala-i-Martin (1992), Convergence I. II Journal of Political Economy. v. 100, No 2. pp. 223-251.

Durlauf, S.N., Quah, D.T. (1999), The New Empirics of Economic Growth I. II Handbook of Macroeconomics. Volume 1. Eddited by J.B. Taylor and M. Woodford. Elsevier, pp. 235-308.

Kaplan, R.S., Norton (2001), The Strategy Focused Organization. Boston, HBS Press (USA).

Sala-i-Martin, X. (1996), The Classical Approach to Convergence Analysis. II The Economic Journal. v. 106 (July). pp. 1019-1036.

Kovinko O. (A. Tanasiichuk) «Marketing mechanism of enterprise management in the conditions of international business diversification»: Dissertation for obtaining a scientific degree of the doctor of economic sciences. Available at: http://abstracts.donnu.edu.ua /article/view/5658/5684. 